\title{
NMDA-receptor antagonists block B-cell function but foster IL-10 production in BCR/CD40-activated B cells
}

\author{
Narasimhulu Simma ${ }^{1 \dagger}$, Tanima Bose ${ }^{2 \dagger}$, Sascha Kahlfuß ${ }^{1 \dagger}$, Judith Mankiewicz ${ }^{1}$, Theresa Lowinus ${ }^{1}$, Fred Lühder ${ }^{3}$, \\ Thomas Schüler', Burkhart Schraven ${ }^{1,4}$, Martin Heine ${ }^{2}$ and Ursula Bommhardt ${ }^{1 *}$
}

\begin{abstract}
Background: $B$ cells are important effectors and regulators of adaptive and innate immune responses, inflammation and autoimmunity, for instance in anti-NMDA-receptor (NMDAR) encephalitis. Thus, pharmacological modulation of B-cell function could be an effective regimen in therapeutic strategies. Since the non-competitive NMDAR antagonist memantine is clinically applied to treat advanced Alzheimer's disease and ketamine is supposed to improve the course of resistant depression, it is important to know how these drugs affect B-cell function.

Results: Non-competitive NMDAR antagonists impaired B-cell receptor (BCR)- and lipopolysaccharide (LPS)-induced B-cell proliferation, reduced B-cell migration towards the chemokines SDF-1a and CCL21 and downregulated IgM and IgG secretion. Mechanistically, these effects were mediated through a blockade of $\mathrm{K}_{v} 1.3$ and $\mathrm{K}_{\mathrm{Ca}_{2}} 3.1$ potassium channels and resulted in an attenuated $\mathrm{Ca}^{2+}{ }^{2}$-flux and activation of Erk1/2, Akt and NFATc1. Interestingly, NMDAR antagonist treatment increased the frequency of $\mathrm{IL}-10$ producing $\mathrm{B}$ cells after BCR/CD40 stimulation.

Conclusions: Non-competitive NMDAR antagonists attenuate BCR and Toll-like receptor 4 (TLR4) B-cell signaling and effector function and can foster IL-10 production. Consequently, NMDAR antagonists may be useful to target B cells in autoimmune diseases or pathological systemic inflammation. The drugs' additional side effects on B cells should be considered in treatments of neuronal disorders with NMDAR antagonists.
\end{abstract}

Keywords: B cell, B10, Ifenprodil, IL-10, $K_{v} 1.3, K_{C a} 3.1$, LPS, Memantine, NMDA-receptor antagonist

\section{Background}

B cells are important mediators of the adaptive immune response by their ability to provide antigen presentation and costimulation for $\mathrm{T}$ cells and to differentiate into antibody secreting plasma cells. B cells are activated through the ligation of their antigen-specific B-cell receptors (BCR) and costimulatory ligands such as CD40, which drive their proliferation, survival and differentiation [1]. In addition, $B$ cells can be stimulated by innate signals like lipopolysaccharide (LPS), a major constituent of the gram-negative bacterial cell wall that binds to Toll-like receptor 4 (TLR4) expressed on B cells

\footnotetext{
* Correspondence: Ursula.Bommhardt@med.ovgu.de

${ }^{\dagger}$ Equal contributors

IInstitute of Molecular and Clinical Immunology,

Otto-von-Guericke-University Magdeburg, Leipziger Str. 44, 39120

Magdeburg, Germany

Full list of author information is available at the end of the article
}

[2,3]. TLR4 plays a pivotal role in the initiation of inflammation and is considered as a potent drug target to prevent severe sepsis, the leading cause of death amongst critically ill patients [4-6]. Systemic inflammation induced by LPS also seems to affect neuronal pathology, for instance in multiple sclerosis, Alzheimer's and Parkinson's disease [7-10].

Ligation of the BCR leads to the activation of several signaling cascades resulting in $\mathrm{Ca}^{2+}$-mobilization [11-13], induction of $\mathrm{Ca}^{2+} /$ calmodulin-dependent transcription factors like NFAT $[14,15]$ and the activation of Erk1/2 and PI-3K-Akt-mTOR signaling pathways [16-20]. The complex TLR4 signaling pathway relies on the recruitment of MyD88 and other adaptor and intermediate signaling molecules to the receptor, but ultimately also involves activation of the MAPK and Akt pathways [21-23]. Activated $B$ cells differentiate into various $B$-cell subsets which 
contribute to a protective humoral immune response. Among them are IL-10 producing regulatory B cells (B10 cells) [24-27] which require for their formation BCR engagement and activation via the CD40 molecule or LPS stimulation [28-30]. B10 cells play a crucial role in preventing inflammatory and autoimmune pathologies $[24,29,31,32]$ and a lack of or inhibition of B10 cells has been associated with exacerbated experimental autoimmune encephalitis (EAE) [33,34], collagen-induced arthritis [35] or colitis in mice [36]. However, B cells can also contribute to or induce diseases by production of auto-antibodies as in rheumatoid arthritis, lupus erythematosus and some neuronal disorders [7,37]. Auto-antibodies against transmitter receptors or voltage-gated ion channels in the brain influence the opening behaviour of neuronal ligand- and voltage-gated ion channels [38], leading to synaptic dysfunction, and are found in Rassmussen encephalitis [39], Lambert-Eaton myasthenic syndrome [40] or anti-N-methyl-D-aspartate-receptor (NMDAR) encephalitis $[41,42]$. Thus, pharmaceuticals that regulate B-cell function by modulating BCR- or TLR4-induced signaling are of interest as anti-inflammatory agents and immunotherapeutics $[43,44]$.

NMDAR antagonists block the activity of ionotropic glutamate receptors of the NMDA type, which play a central role in synaptic transmission, memory formation and neuronal excitotoxicity [45]. NMDAR antagonists like memantine and ketamine are in use or trial to treat neuronal disorders like Alzheimer's disease and resistant depression, respectively $[46,47]$. The possibility of their oral application and their non-competitive action on the channel pore, but not the glutamate binding site, make those antagonists suitable to control the glutamatergic transmission in the brain in chronic treatments of neurological diseases $[48,49]$.

In view of the implication of B cells as source for antibodies against receptors and ion channels causing neuronal autoimmune diseases, their immune regulatory function [50] and role in LPS-induced inflammation [51], we investigated how non-competitive NMDAR antagonists modulate B-cell function. We found that the drugs impair B-cell migration, BCR- and LPS-induced proliferation and immunoglobulin (Ig) production. For both stimulatory conditions, inhibition was mediated through cross-inhibition of $\mathrm{K}_{\mathrm{v}} 1.3$ and $\mathrm{K}_{\mathrm{Ca}} 3.1$ potassium channels and attenuated B-cell signaling. However, antagonist ifenprodil could enhance the production of IL-10, fostering an anti-inflammatory B10 phenotype. Hence, non-competitive NMDAR antagonists may be suitable drugs to dampen pathological inflammatory reactions and to modulate B-cell function in autoimmune diseases. The additional effects of NMDAR antagonists on B cells may be beneficial in treating neuronal disorders.

\section{Results}

NMDAR antagonists block B-cell proliferation induced by BCR or LPS stimulation

Splenic B cells were stimulated with anti-IgM $\left(\mathrm{Fab}^{\prime}\right)_{2}$ fragment goat anti-mouse $(\alpha-\operatorname{IgM})$ to mimic BCR triggering by antigens, or with the TLR4 ligand LPS. B-cell proliferation was determined by ${ }^{3}[\mathrm{H}]$-Thymidine incorporation at $24 \mathrm{~h}$ in the presence or absence of the NMDAR antagonists memantine, an NMDAR open-channel blocker, ifenprodil, a non-competitive inhibitor of the GluN2B subunit of NMDARs, or the competitive NMDAR antagonist D-APV [49,52]. Memantine and ifenprodil inhibited $\alpha$-IgM- as well as LPS-induced DNA synthesis in a concentration dependent manner (Figure $1 \mathrm{~A}$ and $\mathrm{B}$ ). In contrast, the competitive antagonist D-APV had no effect, even at very high doses $(300 \mu \mathrm{M})$. The proliferative response of B cells activated with PMA and ionomycin (IO) was also inhibited by ifenprodil and memantine, but not by D-APV (Figure 1C). Costimulation by CD40 Abs enhanced $\alpha$-IgM- and LPS-induced B-cell proliferation, and under these conditions the antagonists only had a weak inhibitory effect, reducing DNA synthesis by $29-32 \%$, respectively, compared to a $72-90 \%$ reduction in the absence of CD40 stimulation (Figure 1D).

The effects of NMDAR antagonists on apoptosis was evaluated on B cells activated for $24 \mathrm{~h}$ with $\alpha$-IgM, $\alpha-\operatorname{IgM}+\mathrm{CD} 40, \mathrm{LPS}$, and LPS + CD40 (Figure 1E). 5-10\% more apoptotic cells were detected in antagonist-treated cultures whereby ifenprodil had stronger effects than memantine, especially on B cells stimulated with $\alpha$-IgM only. In case of CD40 costimulation, B-cell apoptosis was much lower and both antagonists had no enhancing effect on cell death.

\section{NMDAR antagonists induce membrane depolarization and inhibit $\mathrm{K}_{\mathrm{v}} 1.3$ and $\mathrm{K}_{\mathrm{Ca}} 3.1$ channels in B cells}

We previously reported that protein expression of functional NMDARs in murine $\mathrm{T}$ cells is elusive and that NMDAR antagonists inhibit $\mathrm{K}_{\mathrm{v}} 1.3$ and $\mathrm{K}_{\mathrm{Ca}} 3.1$ channels [53], which are considered as potent targets for immunosuppression [54,55]. These potassium channels are also expressed on B cells and their inhibition was found to differentially influence B-cell proliferation after BCR activation or PMA/IO stimulation [56-59]. Since $\mathrm{K}_{\mathrm{Ca}} 3.1$ and $\mathrm{K}_{\mathrm{v}} 1.3$ channel activities influence membrane depolarization and, thereby, the $\mathrm{Ca}^{2+}$-flux into the cell [60], we first determined the drugs' effects on the membrane potential. Ifenprodil $(20 \mu \mathrm{M})$ and memantine $(30 \mu \mathrm{M})$ reduced the membrane potential of $\alpha$-IgM- or LPS-activated B cells from $\sim-40 \mathrm{mV}$ to $\sim-20 \mathrm{mV}$ and $\sim-10 \mathrm{mV}$, respectively. Addition of $\mathrm{KCl}$ served as a positive control for membrane depolarization (Figure $2 \mathrm{~A}$ ). Next, we recorded $\mathrm{K}_{\mathrm{v}} 1.3$ channel-mediated currents from activated $\mathrm{B}$ cells and the dose response curves in the presence of inhibitors were 
A

B
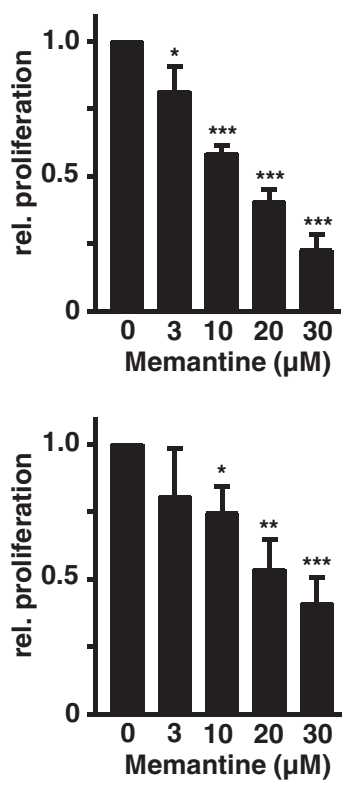

C

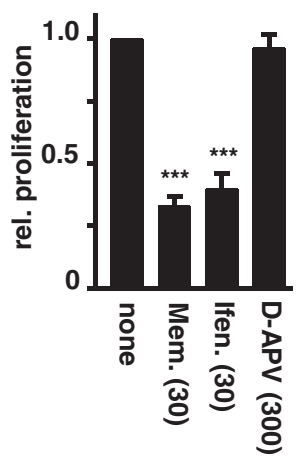

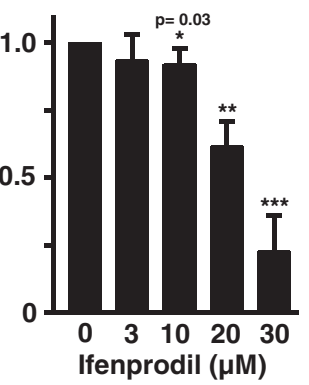
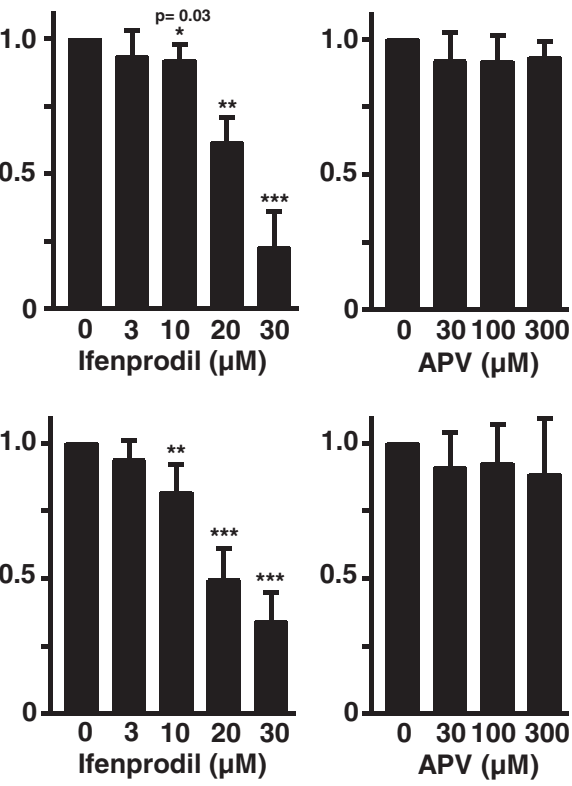

D

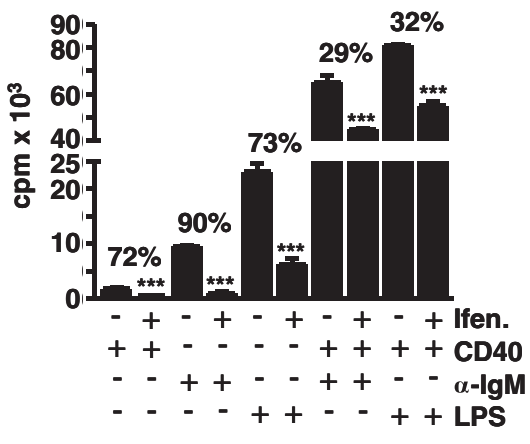

$\mathbf{E}$
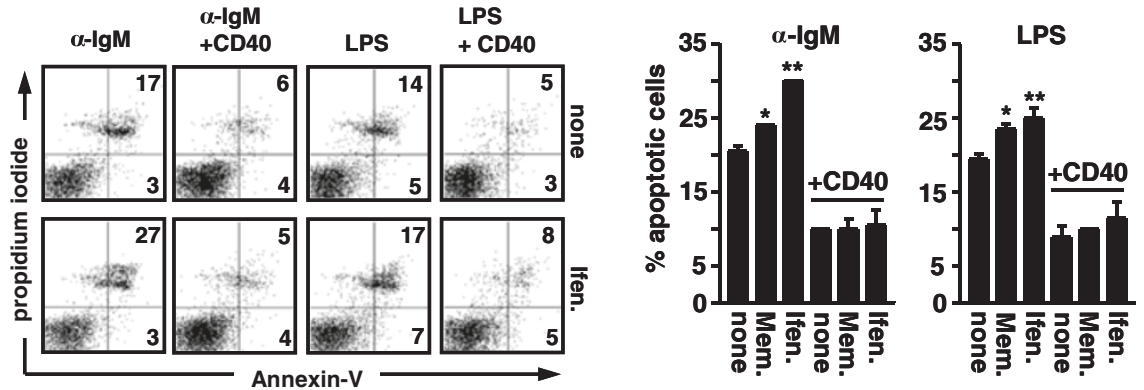

Figure 1 Effects of NMDAR antagonists on B-cell proliferation and apoptosis. A-D) NMDAR antagonists impair BCR-, TLR4- and PMA/IO-induced B-cell proliferation. Splenic B cells were stimulated with A) $a-l g M(10 \mu \mathrm{g} / \mathrm{ml})$ B) LPS $(10 \mu \mathrm{g} / \mathrm{ml})$, C) PMA and ionomycin (IO) or D) $a-\operatorname{lgM}$ or LPS in combination with CD40 Abs $(5 \mu \mathrm{g} / \mathrm{ml})$ in the presence or absence of the indicated concentrations of memantine, ifenprodil or D-APV. Proliferation was determined by ${ }^{3}[\mathrm{H}]$-Thymidine incorporation $(\mathrm{cpm})$ at $24 \mathrm{~h}$. Data in the graphs represent the mean $+\mathrm{SD}$ relative proliferation of at least two experiments. E) NMDAR antagonists enhance B-cell apoptosis. B cells were stimulated with a-lgM or LPS plus/minus CD40 Abs in the presence or absence of ifenprodil or memantine (30 $\mu \mathrm{M}$ each) for $24 \mathrm{~h}$. Apoptosis was measured with Annexin $\mathrm{V}$ and propidium iodide (PI) staining and flow cytometry. The percentage of AnnexinV $\mathrm{V}^{+} \mathrm{Pl}^{-}$early and AnnexinV $\mathrm{PI}^{+}$late apoptotic cells is indicated in the dot plots (left). Data in the right graphs show the percentage of apoptotic cells as mean + SD calculated from two experiments. 

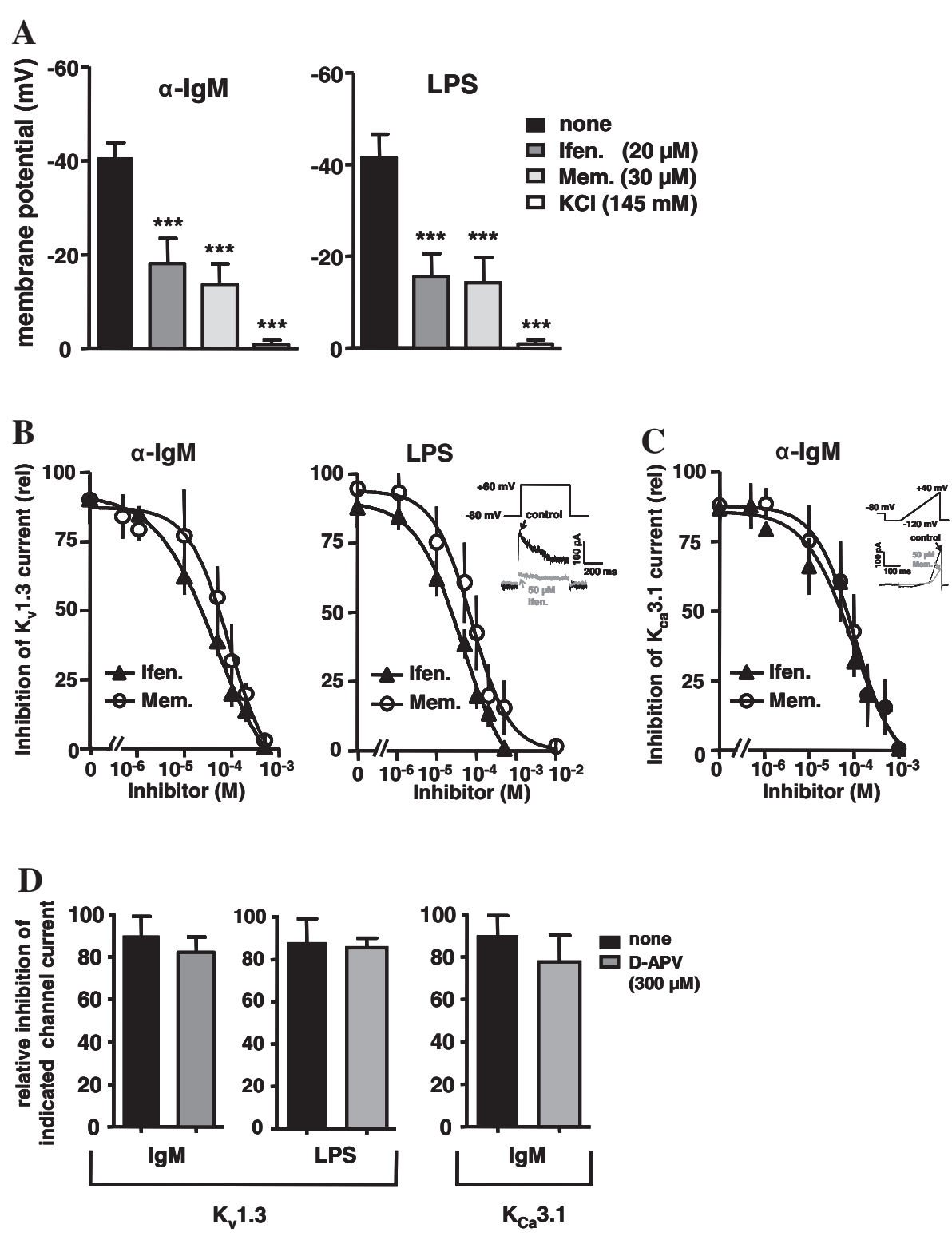

Figure 2 Effects of NMDAR antagonists on B-cell membrane potential and $\mathbf{K}^{+}$channel activity. B cells were activated with a-lgM or LPS $(10 \mu \mathrm{g} / \mathrm{ml}$ each) for 24-48 h. A) NMDAR antagonists lead to a depolarization of the membrane potential. Activated B cells were analyzed for changes in the membrane potential upon addition of ifenprodil or memantine in concentrations as indicated. $\mathrm{KCl}$ treatment served as a control for cell integrity. B-D) Ifenprodil and memantine inhibit $\mathrm{K}^{+}$channel activity. Dose-inhibition curves of B) $\mathrm{K}_{\mathrm{v}} 1.3$ and $\mathbf{C}$ ) $\mathrm{K}_{\mathrm{Ca}} 3.1$ channels in the presence of ifenprodil or memantine were plotted from the recorded maximal transient currents. Insets show one particular trace of control and

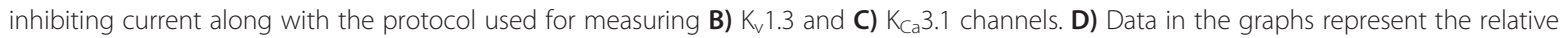
inhibition of $\mathrm{K}_{\mathrm{v}}$ 1.3- and $\mathrm{K}_{\mathrm{C}_{\mathrm{a}}} 3.1$-mediated currents in the presence of the competitive NMDAR antagonist D-APV. All data were calculated from 5-6 cells of four experiments and are represented as mean \pm SD.

calculated from maximal transient current amplitudes. Ifenprodil and memantine markedly reduced $\mathrm{K}_{\mathrm{v}} 1.3$ channel currents irrespective whether B cells were stimulated with $\alpha$-IgM or LPS (Figure 2B). $\mathrm{IC}_{50}$ and Hill slope values for $\alpha$-IgM-activated B cells were $\sim 20 \mu \mathrm{M}$ and $\sim 1.3$ for ifenprodil and $\sim 40 \mu \mathrm{M}$ and $\sim 1.8$ for memantine. For LPS-treated B cells, $\mathrm{IC}_{50}$ and Hill slope values were $\sim 18 \mu \mathrm{M}$ and $\sim 1.4$ for ifenprodil and $\sim 45 \mu \mathrm{M}$ and $\sim 1.2$ for memantine. For B cells stimulated by BCR ligation, we additionally recorded $\mathrm{K}_{\mathrm{Ca}} 3.1$ channel-mediated currents (Figure 2C). $\mathrm{K}_{\mathrm{Ca}} 3.1$ currents were not detected in LPS-activated $\mathrm{B}$ cells. $\mathrm{IC}_{50}$ values for ifenprodil and memantine were $\sim 30 \mu \mathrm{M}$ and $\sim 50 \mu \mathrm{M}$ and Hill slopes were $\sim 1.4$ and $\sim 1.6$. However, the competitive NMDAR antagonist D-APV, which blocks neuronal NMDARs at the $1 \mu \mathrm{M}$ range, had no effect on $\mathrm{K}_{\mathrm{v}} 1.3$ and $\mathrm{K}_{\mathrm{Ca}} 3.1$ channels, even at 10-time higher 
concentrations $(300 \mu \mathrm{M})$ (Figure 2D). Thus, $\mathrm{K}_{\mathrm{v}} 1.3$ and $\mathrm{K}_{\mathrm{Ca}} 3.1$ channels, whose specific blockade abolishes B-cell activation [56,59], are partially inhibited by the non-competitive NMDAR antagonists ifenprodil and memantine.

\section{BCR- and LPS-induced B-cell signaling is attenuated by NMDAR antagonist}

Next, we assessed the antagonists' effects on B-cell signaling and $\mathrm{Ca}^{2+}$ mobilization, which is critical for B-cell activation and proliferation [11,13,61]. Indo-1 AM-labelled B cells showed a concentration-dependent inhibition of $\mathrm{BCR}$-induced $\mathrm{Ca}^{2+}$-flux upon treatment with ifenprodil or memantine (Figure 3A). Furthermore, the levels of phosphorylated Akt, S6 and Erk1/2 were significantly lower in $\alpha$-IgM-activated B cells in the presence of ifenprodil compared to untreated cells (Figure 3B, left panel). Notably, B cells stimulated with LPS showed a very similar inhibition of Akt, S6 and Erk1/2 activation by ifenprodil (Figure 3B, right panel). In long-term stimulation, $\alpha$-IgM- and LPS-activated B cells cultured with ifenprodil exhibited lower levels of pErk1/2 and pS6 in the cytoplasm (Figure 3C) and a reduced nuclear accumulation of pErk1/2 and NFATc1 (Figure 3D). Thus, NMDAR antagonists downregulate major signaling events of two distinct B-cell activating receptors that play an important role in innate and antigen-specific B-cell responses $[18,62]$. Since CD40 costimulation rescued the inhibitory effects of NMDAR antagonists on BCR-induced B-cell proliferation and apoptosis (Figure 1), we analysed pErk1/2 and pS6 expression under costimulatory conditions and found an enhanced activation of both signaling molecules compared to $\alpha$-IgM stimulation alone (Figure 3E). However, although addition of ifenprodil reduced pErk $1 / 2$ and pS6 levels in $\alpha$-IgM + CD40-treated B cells, these levels were still above those found after $\alpha$-IgM treatment. Hence, antagonist-induced attenuated signaling in CD40 costimulated B cells is still above a critical threshold needed for B-cell activation.

\section{NMDAR antagonists impair B-cell migration and Ig production}

The migratory response of $\mathrm{B}$ cells within the activating lymphoid environment or at inflammatory sites is a key feature for their differentiation and function. We investigated whether NMDAR antagonists affect chemokineinduced migration and found a strong reduction in the migratory response of $\mathrm{B}$ cells to the chemokines SDF- $1 \alpha$ and CCL21 in the presence of ifenprodil (Figure 4A). Antibody secretion is the major effector function of $B$ cells. In order to determine the impact of ifenprodil on IgM and IgG production, B cells were stimulated with LPS or LPS + IL-4. Ifenprodil was added at days 1, 2 or 3 and ELISA was performed at day 4. As shown in
Figure $4 \mathrm{~B}$, the blockade of $\operatorname{IgM}$ and $\operatorname{IgG}$ secretion was most efficient after addition of ifenprodil at day 1 . With increasing time, the inhibitory effect of ifenprodil declined but was still detectable. Hence, NMDAR antagonists not only inhibit $\mathrm{B}$ cell proliferation and migration but also antibody secretion.

\section{NMDAR antagonists modulate IL-10 production}

Since several B-cell responses were negatively regulated by NMDAR antagonists, we asked whether the druginduced attenuated signaling would influence the production of IL-10, the immunosuppressive cytokine made by B10 cells [18,32,33,35]. Mitogenic stimulation of B cells with PMA and IO leads to the induction of IL-10 mRNA $[24,31,63]$. Thus, we stimulated B cells with these mitogens for $16 \mathrm{~h}$ in the absence or presence of ifenprodil. Drug treatment lead to a strong repression of IL-10 transcripts compared to untreated B cells (Figure 5A). We then asked whether ifenprodil has effects on B cells that were pre-activated with $\alpha$-IgM + CD40 Abs, LPS or agonistic CD40 Abs, which are known to give rise to regulatory B10 cells [25,28,35,64]. Ifenprodil was added at day 1 , and IL-10 and IFN- $\gamma$ production were determined at day 2 or 3 (Figure $5 \mathrm{~B}$ ). IFN- $\gamma$ production was not altered by ifenprodil. Low levels of IL-10 production were induced in $8 \%$ of $\alpha$-IgM + CD40-stimulated and in $19-27 \%$ of CD40- or LPS-activated B cells, which showed low to high levels of IL-10. Ifenprodil had either no effect or lowered the percentage of IL-10 producing B cells in CD40- or LPS-stimulated cultures. In contrast, addition of ifenprodil to $\alpha$-IgM + CD40-activated B cells increased the frequency of IL-10 producers 1.5-2-fold, although absolute IL-10 expression levels remained low. Experiments with B cells from IL-10-GFP knock-in tiger mice [65] supported these results. $\alpha$-IgM + CD40-activated B cells, with ifenprodil treatment started after 21-25 h, showed a $50 \%$ increase in the percentage of IL-10-GFP ${ }^{+}$ $\mathrm{B}$ cells at day 2 (Figure 5C) and when measured at day 4 a 6-fold increase (Figure 5D). Therefore, ifenprodil can foster the generation of an IL-10 producing phenotype.

\section{Discussion}

Here, we show that non-competitive NMDAR antagonists attenuate adaptive (BCR) as well as innate (LPS/ TLR4) B-cell signaling. The drugs inhibited IgM and IgG secretion, B cell migration and impaired B-cell proliferation and viability, which were partially overcome by CD40 costimulation. Since the non-competitive antagonists ifenprodil and memantine, but not the competitive antagonist D-APV, blocked the activity of $\mathrm{K}_{\mathrm{v}} 1.3$ and $\mathrm{K}_{\mathrm{Ca}} 3.1$ channels, the used non-competitive antagonists seem to act mainly via inhibition of those $\mathrm{K}^{+}$channels, which maintain a favourable electrochemical gradient that is required for a sustained $\mathrm{Ca}^{2+}$-entry through $\mathrm{Ca}^{2+}$-release 


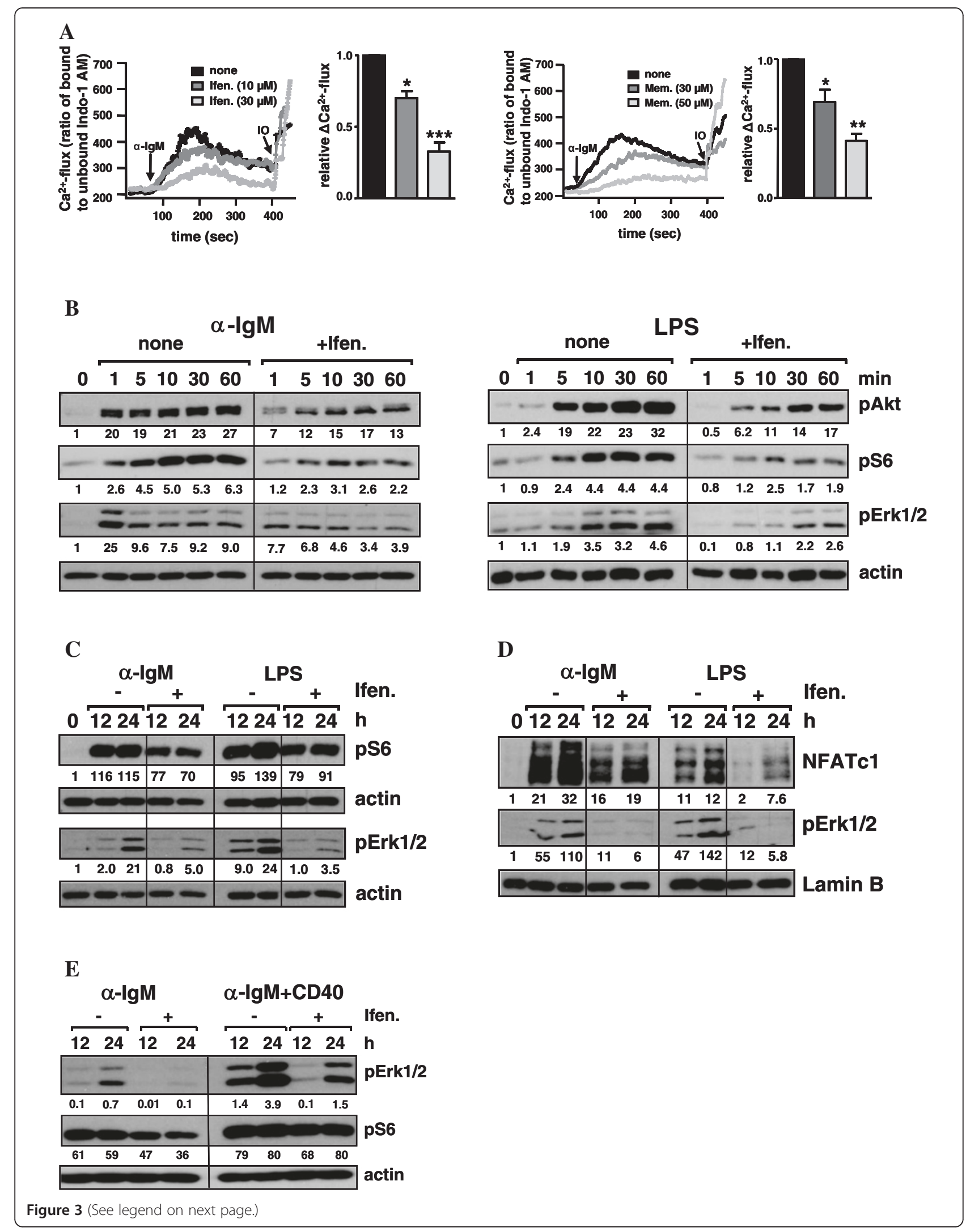


(See figure on previous page.)

Figure 3 Effects of NMDAR antagonists on B-cell signaling. A) Reduced $\mathrm{Ca}^{2+}$-flux in BCR-activated B cells in the presence of NMDAR antagonists. Indo-1 AM-labelled B cells were stimulated with a-lgM $(10 \mu \mathrm{g} / \mathrm{ml})$ in the presence or absence of ifenprodil (left) or memantine (right) and $\mathrm{Ca}^{2+}{ }_{-}$flux was determined by flow cytometry. Corresponding graphs show the mean $+\mathrm{SD}$ relative $\Delta \mathrm{Ca}^{2+}$-flux of three experiments. B-E) NMDAR antagonists

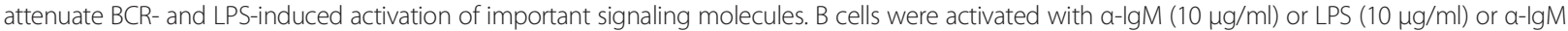
plus CD40 Abs $(5 \mu \mathrm{g} / \mathrm{ml})$ in the presence or absence of ifenprodil $(30 \mu \mathrm{M})$ in $\mathbf{B})$ short-term and C-E) long-term stimulation. Activation of the indicated signaling proteins in B) total, C, E) cytoplasmic and D) nuclear protein extracts was analyzed by Western blot. $\beta$-Actin and Lamin B expression served as controls for protein loading. Indicated numbers give the relative protein expression after quantification and normalization to controls. Data are the representative of two $\mathbf{( E )}$ and three (B-D) independent experiments.

activated channels (CRAC) $[15,66]$. Due to the similar action of the non-competitive NMDAR antagonists on $\mathrm{K}_{\mathrm{v}} 1.3$ and $\mathrm{K}_{\mathrm{Ca}} 3.1$ channels as described for the action of specific $\mathrm{K}^{+}$channel inhibitors [57-59], a differential modulation seems excluded and is probably the cause for their effects reported here. In line with the inhibition of both $\mathrm{K}^{+}$channel types in B cells, BCR-induced $\mathrm{Ca}^{2+}$-flux was reduced and BCR- and TLR4-induced downstream activation of Erk1/2, Akt, S6, and NFATc1 was dampened. Ifenprodil added to $\mathrm{B}$ cells pre-activated with BCR/CD40 Abs fostered IL-10 production, but when added at the beginning of B-cell stimulation reduced IL-10 transcripts. Thus, the enhancement of IL-10 production seems to depend on the timing and concentration of drug application, although further experimentation is required for identification of the underlying mechanisms. IL-10 expression is regulated by $\mathrm{Ca}^{2+}$-level [63], Bruton's tyrosine kinase (Btk), the adaptor protein BLNK/SLP65, CamKII, Erk1/2, and transcription factors like CREB, STAT3, NFKB or NFAT $[13,18,67-72]$. The activation of Erk1/2 in B cells in turn is dependent on $\mathrm{Ca}^{2+}$-flux and PI-3K activation $[73,74]$. IL-10 secretion is differentially controlled depending on the activation stimulus and availability of IL-21 $[26,75]$. Furthermore, IL-10 production by B10 cells seems to be transient [76]. We found that ifenprodil impairs BCR/CD40-induced Erk1/2 and Akt activation and thus speculate that upon ifenprodil treatment subtle differences in $\mathrm{Ca}^{2+}$-level [77] and the activity of Erk1/2, Akt and other signaling molecules favour IL-10 production. Interestingly, genetic deletion or inhibition of $K_{v} 1.3$ channels in $T$ cells was found to increase IL-10 production in T cells along with an amelioration of experimental autoimmune encephalomyelitis and allergic asthma [78,79]. Since NMDAR antagonists block $\mathrm{K}_{\mathrm{v}} 1.3$ and $\mathrm{K}_{\mathrm{Ca}} 3.1$ channels in $\mathrm{B}$ cells, the increase of IL-10 production in BCR/CD40-activated B cells may result from similar mechanisms.

Our data suggest that application of non-competitive NMDAR antagonists during chronic treatments of neurological disorders like Alzheimer`s disease may not only involve neuronal NMDARs, but may also have additive
A

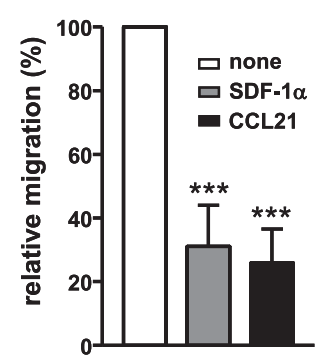

B

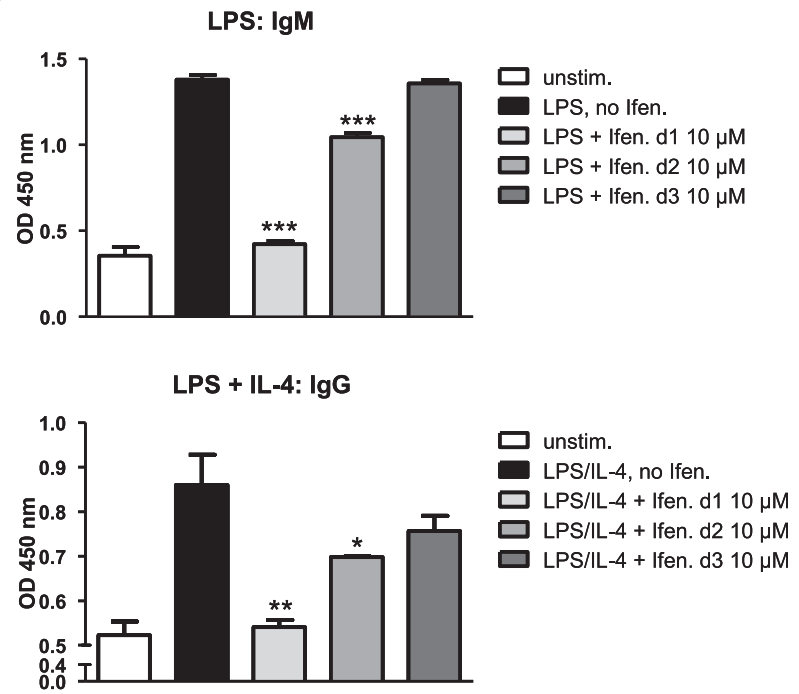

Figure 4 NMDAR antagonists affect B-cell migration and Ig production. A) Ifenprodil impairs chemokine-induced B-cell migration. The migration of splenic B cells towards SDF-1a and CCL21 in the absence or presence of ifenprodil (30 $\mu \mathrm{M})$ was determined and the relative + SD migration was calculated from three experiments. Migration of B cells in the absence of ifenprodil was set as 100\%. B) Ifenprodil blocks lg production. B cells were activated with LPS or LPS plus IL-4 in the presence or absence of ifenprodil $(10 \mu \mathrm{M})$ and IgM and IgG secretion was determined at day 4 with ELISA. Ifenprodil was added at day 1, day 2 or day 3. Data are representative for two experiments. 
$\mathbf{A}$

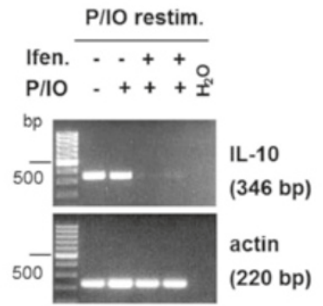

B

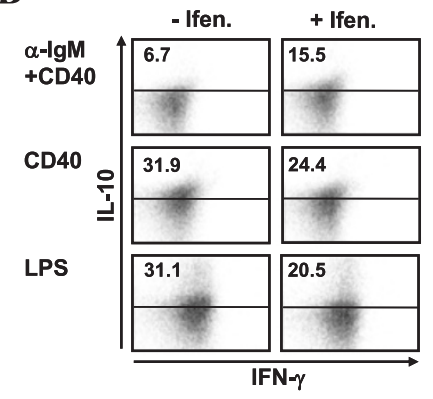

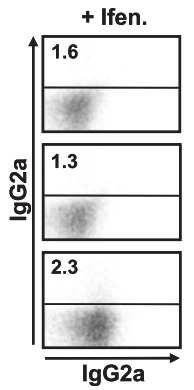

C
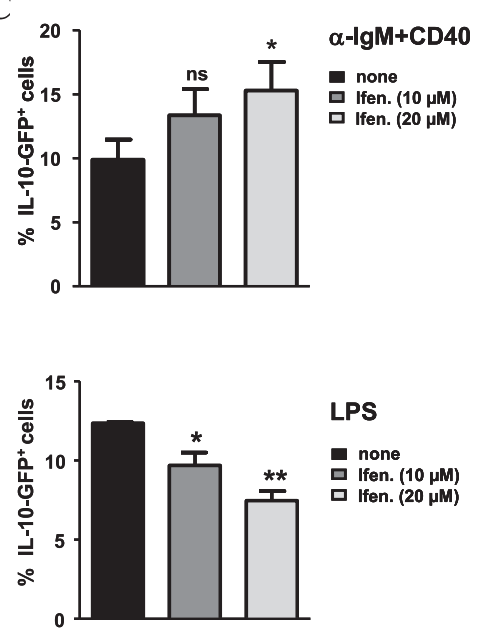

D

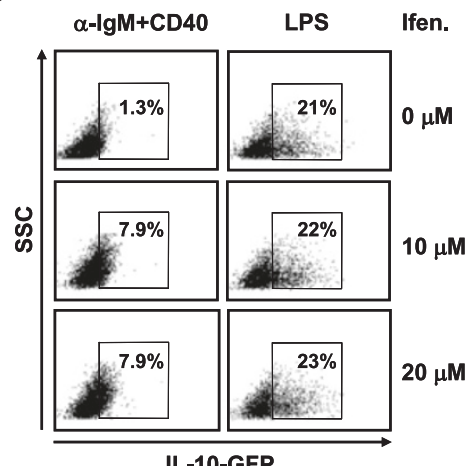

Figure 5 Ifenprodil modulates IL-10 production of B cells. A) Ifenprodil reduces IL-10 mRNA transcripts in PMA/IO-activated B cells. Splenic B cells were left untreated or were activated with PMA and IO in the absence or presence of ifenprodil (10 and $30 \mu \mathrm{M}$, lanes 3 and 4$)$ for $16 \mathrm{~h}$. Cells were restimulated with PMA/IO and monensin for $6 \mathrm{~h}$ and RT-PCR for IL-10 and $\beta$-actin expression was performed. Data are the representative of two experiments. B-D) IL-10 production in BCR + CD40-stimulated B cells is enhanced upon ifenprodil treatment. B) B cells were activated with $\mathrm{a}-\operatorname{lgM}+\mathrm{CD} 40, \mathrm{CD} 40$ Abs alone or LPS for 2-3 days. Ifenprodil $(10 \mu \mathrm{M})$ was added at day 1 . The production of IFN- $\gamma$ and IL-10 was analyzed by intracellular staining and flow cytometry. The percentage of cells positive for IL-10 (gates were set according to staining with isotype controls, right panel) is indicated in each dot plot. The graphs represent the relative + SD percentage of IL-10 expressing B cells in a-lgM + CD40, CD40 and LPS cultures treated with ifenprodil. For each stimulation condition, data were related to the percentage of IL-10 $\mathrm{B}$ cells generated in the absence of ifenprodil, which was set as 1.0. Data for $48 \mathrm{~h}$ were calculated from three, for $72 \mathrm{~h}$ from two to four experiments. C, D) B cells from IL-10-GFP tiger mice were activated with a-IgM+CD40 or LPS. Ifenprodil (10 and $20 \mu \mathrm{M})$ was added after 21-25 h and expression of IL-10-GFP at C) day 2 or D) day 4 was determined with flow cytometry. Data are from two independent experiments.

side-effects by targeting B cells, which are assumed to contribute to these disorders $[7,9,10]$. Given that the drugs impaired several B-cell functions, but enhanced IL-10 production in BCR/CD40-stimulated B cells, their employment in systemic inflammation or autoimmune diseases, for instance in sepsis or anti-NMDAR encephalitis, appears promising. Here, antagonists may limit B-cell hyper-reactivity and antibody production or mediate immunomodulation or suppression through an enhanced frequency of IL-10 secreting B cells. IL-10 producing $\mathrm{B}$ cells also target $\mathrm{T}$ cells as they induce IL-10 producing $\mathrm{CD}^{+}{ }^{+} \mathrm{T}$ cells, suppress Th1 cell differentiation and increase the number of $\mathrm{CD} 4^{+} \mathrm{CD} 25^{+} \mathrm{Foxp} 3^{+}$regulatory $\mathrm{T}$ cells in vivo [29]. Furthermore, although action of noncompetitive NMDAR antagonists on memory B cells is not investigated, pharmacological modulation of memory Bcell differentiation or secondary B-cell responses can be envisaged. Since specific blockade of $\mathrm{K}_{\mathrm{v}} 1.3$ and $\mathrm{K}_{\mathrm{Ca}} 3.1$ channels results in immunosuppression of $\mathrm{T}$ and $\mathrm{B}$ cells $[54,59]$ and non-competitive NMDAR antagonists block these two $\mathrm{K}^{+}$channels in B cells, application of NMDAR antagonists may also be useful to treat acute and chronical allograft 
rejections driven by B cells. Memantine, which passed clinical trials and is in use to treat advanced Alzheimer's disease, might show similar effects as the specific $\mathrm{K}_{\mathrm{v}} 1.3$ and $\mathrm{K}_{\mathrm{Ca}} 3.1$ blockers Shk and TRAM-34 in treating allograft vasculopathy or kidney allograft rejection $[80,81]$. However, further studies are required to determine the drug's suitability for in vivo treatment of these immune disorders.

\section{Conclusions}

Through their nonspecific action on $\mathrm{K}_{\mathrm{v}} 1.3$ and $\mathrm{K}_{\mathrm{Ca}} 3.1$ potassium channels, non-competitive NMDAR antagonists are potent modulators of LPS/TLR4- and BCRinduced proliferation, migration, Ig production and anti-inflammatory IL-10 production by B cells. Thus, they may be useful to target B cells under pathological inflammatory conditions. They may also have beneficial side effects during chronic treatments of neurological disorders like Alzheimer's disease.

\section{Methods \\ Mice}

C57BL/6 mice were used at the age of 6-10 weeks. IL-10-GFP knock-in mice, designated interleukin-ten ires gfp-enhanced reporter (tiger) mice [65] were 8 or 28 weeks old and kindly provided by J. Hühn, HZI Braunschweig, Germany. All animal work performed was in compliance with the German and local guidelines for the Use of Experimental Animals.

\section{Cell isolation and proliferation assay}

Splenic B cells were isolated with the B-cell isolation kit from Miltenyi Biotech (Bergisch Gladbach, Germany) according to the manufacturer's protocol. Purity of $\mathrm{B}$ cells was $90-95 \%$. B cells were activated with $\alpha$-IgM $(10 \mu \mathrm{g} / \mathrm{ml}$, Jackson Immunoresearch Laboratories, Hamburg, Germany), lipopolysaccharide (LPS, $10 \mu \mathrm{g} / \mathrm{ml}$, E. coli 0111:B4, Sigma-Aldrich, Taufkirchen, Germany), or PMA (100 ng/ml, Calbiochem, Darmstadt, Germany) and IO (700 ng/ml, Sigma) in complete RPMI1640 medium (Biochrom AG, Berlin, Germany) supplemented with 10\% FCS, $50 \mu \mathrm{M} \beta$-mercaptoethanol, $1 \%$ penicillin/streptomycin. NMDAR antagonist ifenprodil, memantine, or D-APV (diluted in $\mathrm{dd}_{2} \mathrm{O}$, all from Tocris Biosciences, Bristol, Great Britain) were added in concentrations as given. Proliferation was measured at $24 \mathrm{~h}$ of culture by ${ }^{3}[\mathrm{H}]$-Thymidine incorporation $(0.2 \mu \mathrm{Ci} /$ well, MP Biochemicals Europe, Heidelberg, Germany) for $16 \mathrm{~h}$.

\section{Apoptosis measurement}

Apoptosis was determined with the Apoptosis detection kit from BD Pharmingen (Heidelberg, Germany). $2 \times 10^{5}$ splenic B cells were left untreated or were activated with $\alpha$-IgM $(10 \mu \mathrm{g} / \mathrm{ml})$ or LPS $(10 \mu \mathrm{g} / \mathrm{ml})$ without or with costimulation by CD40 Abs $(5 \mu \mathrm{g} / \mathrm{ml}$, Biolegend, San
Diego, CA, USA) in the presence or absence of ifenprodil (30 $\mu \mathrm{M}$, Tocris Biosciences). At $24 \mathrm{~h}$ of culture cells were harvested, stained with Annexin V-FITC (BD Pharmingen) and propidium iodide (PI, Sigma-Aldrich) according to manufacturer's protocol and analyzed by flow cytometry using a FACSFortessa and Cell Quest software (BD Biosciences). The percentage of viable cells was determined by gating on Annexin $\mathrm{V}^{-} \mathrm{PI}^{-}$cells.

\section{Western blot}

$5 \times 10^{6}$ splenic B cells were activated with $\alpha$-IgM $(10 \mu \mathrm{g} / \mathrm{ml})$, LPS $(10 \mu \mathrm{g} / \mathrm{ml})$ or $\alpha$-IgM $(10 \mu \mathrm{g} / \mathrm{ml})$ plus CD40 Abs $(5 \mu \mathrm{g} / \mathrm{ml})$ in the presence or absence of ifenprodil $(30 \mu \mathrm{M})$ for the indicated time points. Cells were lysed and total, cytoplasmic or nuclear protein extracts were obtained as described before [82]. Protein lysate (10-15 $\mu \mathrm{g})$ was subjected to $8-10 \%$ SDS-PAGE and proteins were transferred onto nitrocellulose membrane, which was blocked with $5 \%$ non-fat milk powder in TBST. Primary Abs for the detection of signaling proteins were: pErk1/2 $\left(\mathrm{Thr}^{202} /\right.$ $\mathrm{Tyr}^{204}$ ), pAkt (Ser $\left.{ }^{473}, \mathrm{DE} 9\right), \mathrm{pS6}\left(\mathrm{S}^{240 / 244}\right)$ (all from Cell Signaling Technology, Frankfurt, Germany), NFATc1 (7A6, Alexis Biochemicals, Lörrach, Germany), $\beta$-actin (AC 40, Sigma-Aldrich), and Lamin-B (Santa Cruz, Biotechnology, Santa Cruz, CA, USA). HRP-coupled mouse anti-rabbit, goat anti-mouse or donkey anti-goat secondary Abs (Jackson ImmunoResearch Laboratories, Dianova) and the ECL detection system (Thermo Scientific Pierce, Rockford, IL, USA) were applied to reveal primary antibodies. Quantification of immune reactive bands was done with Kodak software.

\section{$\mathrm{Ca}^{2+}$-flux measurement}

Splenocytes were stained with Indo-1 AM $(4 \mu \mathrm{M}$, Life Technologies, Darmstadt, Germany) for $45 \mathrm{~min}$ at $37^{\circ} \mathrm{C}$. Cells were washed, stained for CD8 and CD4 surface expression and suspended in Hank's buffer (Biochrom) supplemented with $1 \mathrm{mM} \mathrm{CaCl}$. NMDAR antagonists ifenprodil $(10$ or $30 \mu \mathrm{M})$ and memantine (30 or $50 \mu \mathrm{M})$ were added for 5 min before B cells were activated with $\alpha$-IgM $(10 \mu \mathrm{g} / \mathrm{ml})$ to induce $\mathrm{Ca}^{2+}$-flux. Ionomycin (IO, $2 \mu \mathrm{M}$, Calbiochem) was added at the end to control cell reactivity. $\mathrm{Ca}^{2+}$-flux was measured with a LSRII flow cytometer (BD Biosciences). Data were analyzed with FlowJo V3.6.1 software (Tree Star, Ashland, OR, USA), mean $\mathrm{Ca}^{2+}$-flux of unlabelled $\mathrm{B}$ cells was calculated and data were further processed by IgorPro5.04B software (WaveMetrics Inc., Portland, OR, USA). $\Delta \mathrm{Ca}^{2+}$-flux represents the difference between the maximum and minimum values of $\mathrm{Ca}^{2+}$-intensity.

\section{Migration assay}

Splenocytes $\left(4 \times 10^{6}\right)$ were left untreated or were incubated with ifenprodil $(30 \mu \mathrm{M})$ for $30 \mathrm{~min}$ in D-MEM medium 
(Biochrom) supplemented with 0.1\% BSA and $10 \mathrm{mM}$ HEPES pH7.4. Cells were transferred unto fibronectincoated $(6.5 \mu \mathrm{g} / \mathrm{ml}$, Roche Diagnostics, Basel, Switzerland) transwell chambers $(3.0 \mu \mathrm{m}$ pore size, Corning Costar, Tewksburry, MA, USA) and SDF- $1 \alpha(100 \mathrm{ng} / \mathrm{ml})$ or CCL21 (300 ng/ml, both from PeproTech, Hamburg, Germany) was added. Migration was performed for $150 \mathrm{~min}$ at $37^{\circ} \mathrm{C}$ and stopped with $0.1 \mathrm{M}$ EDTA. Migrated cells were stained with rat anti-mouse B220-FITC Ab (RA3-6B2, BD Pharmingen) and measured for $30 \mathrm{~s}$ at a FACS Fortessa. The number of $\mathrm{B}$ cells migrated in the presence of chemokine (set as 1.0) was divided by the number of cells migrated in the absence of chemokine to obtain the relative migration values.

\section{Intracellular cytokine staining and IL-10-GFP induction}

Splenic B cells were stimulated with $\alpha$-IgM $(10 \mu \mathrm{g} / \mathrm{ml})$ plus CD40 Abs $(5 \mu \mathrm{g} / \mathrm{ml})$, CD40 Abs alone $(5 \mu \mathrm{g} / \mathrm{ml})$, or LPS $(10 \mu \mathrm{g} / \mathrm{ml})$ for $48 \mathrm{~h}$ or $72 \mathrm{~h}$. Ifenprodil $(10 \mu \mathrm{M})$ was added once and at day 1 . Before harvest, cells were treated with IO $(800 \mathrm{ng} / \mathrm{ml})$ and PMA $(500 \mathrm{ng} / \mathrm{ml})$ for $4 \mathrm{~h}$ in the presence of Brefeldin A (3 $\mu \mathrm{g} / \mathrm{ml}$, all from Calbiochem). Thereafter, cells were fixed and stained with IL-10-PE and IFN- $\gamma$-FITC Abs using IgG2b-PE/FITC isotype controls (all from eBiosciences, Frankfurt, Germany) and the FoxP3 staining buffer kit (eBiosciences) according to manufacturer's protocol. Cells were analyzed by flow cytometry and the percentage of live cells producing IL-10 or IFN- $\gamma$ was determined with Cell-Quest Pro. B cells isolated from IL-10-GFP tiger mice were activated with $\alpha$-IgM/CD40 or LPS and cultured in 96-well plates for 2 or 4 days. Ifenprodil $(10$ and $20 \mu \mathrm{M})$ was added at 21-25 $\mathrm{h}$ and cells were harvested either at day 2 or day 4 . Before harvest, cells were re-stimulated with PMA $(100 \mathrm{ng} / \mathrm{ml})$ and $\mathrm{IO}(800 \mathrm{ng} / \mathrm{ml})$ and monensin $(10 \mu \mathrm{g} / \mathrm{ml})$ for $4 \mathrm{~h}$. IL-10-GFP expression was analyzed on gated live cells with flow cytometry.

\section{Electrophysiology}

For all experiments the whole-cell configuration of the patch-clamp technique was applied at room temperature (RT) $\left(20-24^{\circ} \mathrm{C}\right)$ using an EPC10 amplifier and PatchMaster v.2.11 (HEKA Electronic, Lambrecht, Germany). Patch pipettes from borosilicate glass used for recordings had a resistance between 3-5 M . For recording $\mathrm{K}_{\mathrm{v}} 1.3$ currents the external solution contained $145 \mathrm{mM} \mathrm{NaCl}, 5 \mathrm{mM}$ $\mathrm{KCl}, 10 \mathrm{mM}$ HEPES, $1 \mathrm{mM} \mathrm{MgCl}$, $2.5 \mathrm{mM} \mathrm{CaCl}_{2}$, $5.5 \mathrm{mM}$ glucose, pH7.4 $(\mathrm{NaOH})$. The pipette solution contained $140 \mathrm{mM}$ KF, $11 \mathrm{mM}$ EGTA, $10 \mathrm{mM}$ HEPES, $1 \mathrm{mM} \mathrm{CaCl}_{2}, 2 \mathrm{mM} \mathrm{MgCl}$, pH7.2 (KOH) [83]. In both cases osmolarity was set to 300-340 mOsM. $\mathrm{K}_{\mathrm{v}} 1.3$ currents were measured with depolarizing voltage steps up to $+60 \mathrm{mV}$ from a holding potential of $-80 \mathrm{mV}$ every $30 \mathrm{~s}$ and sampling rate of $5 \mathrm{kHz} . \mathrm{K}_{\mathrm{Ca}} 3.1$ channel currents were measured with an external solution composed of $160 \mathrm{mM} \mathrm{Na}$-aspartate, $4.5 \mathrm{mM} \mathrm{KCl}, 2 \mathrm{mM} \mathrm{CaCl} 2,1 \mathrm{mM}$ $\mathrm{MgCl}_{2}, 10 \mathrm{mM}$ HEPES and an internal solution of $145 \mathrm{mM}$ K-aspartate, $8.5 \mathrm{mM} \mathrm{CaCl}, 2 \mathrm{mM} \mathrm{MgCl}_{2}$, $10 \mathrm{mM}$ EGTA, $10 \mathrm{mM}$ HEPES adjusted to pH7.4 and $\mathrm{pH} 7.2$, respectively. This current was recorded by a $200 \mathrm{~ms}$ voltage ramp from -120 to $+40 \mathrm{mV}$ from a holding potential of $-80 \mathrm{mV}$ every $15 \mathrm{~s}$. For membrane potential experiments, cells were recorded in the current clamp mode with $0 \mathrm{pA}$ holding current immediately after establishment of the whole-cell configuration. Ifenprodil, memantine or D-APV (Tocris) were added during the recording with a constant inhibitor concentration. Transient currents were analyzed in HEKA FitMaster v. $2 \times 53$ and GraphPad Prism 5.0 to determine the dose-response curve and Hill slope and statistical analysis.

\section{RNA isolation and RT-PCR}

Splenic B cells were stimulated with PMA (100 ng/ml) and IO $(700 \mathrm{ng} / \mathrm{ml})$ for $16 \mathrm{~h}$ in the presence or absence of ifenprodil $(20$ and $30 \mu \mathrm{M})$ or were left unstimulated. Before harvest cells were re-stimulated for an additional $6 \mathrm{~h}$ with PMA and IO and monensin $(10 \mu \mathrm{g} / \mathrm{ml})$. RNA was extracted with TRIzol reagent (Life Technologies, Darmstadt, Germany) and reverse transcribed with a First-Strand cDNA Synthesis Kit (Thermo Scientific, Karlsruhe, Germany) according to the manufacturer's protocol. PCR primers were: IL-10: forward 5'TGCCTTCAGT CAAGTGAAGACT-3' and reverse 5'-AAACTCATTC ATGGCCTTGTA-3' and $\beta$-actin: forward 5'-CCAGGT CATCACTATTGGCAAGGA-3 and reverse 5 -GAGCA GTAATCT CCTTCTGCATCC-3'.

\section{ELISA}

For detection of secreted IgM and IgG, B cells were activated with LPS $(10 \mu \mathrm{g} / \mathrm{ml})$ or LPS plus IL-4 $(20 \mathrm{ng} / \mathrm{ml}$, ImmunoTools, Friesoythe, Germany) in triplicates in 96well plates (Nunc Maxisorp, Thermo Fisher-Scientific, Marietta, $\mathrm{OH}, \mathrm{USA})$. Ifenpodil $(10 \mu \mathrm{M})$ was added at day 1 , day 2 or day 3 and culture supernatant was taken on day 4. Plates were coated over night with $50 \mu \mathrm{l}$ goat anti-mouse Ig (Southern Biotech, Birmingham, AL, USA) 1:500 in $50 \mathrm{mM}$ sodium carbonate puffer. After washing with $\mathrm{PBS} / 0.05 \%$ Tween 20 the wells were blocked with $\mathrm{PBS} / 5 \%$ BSA for $1 \mathrm{~h}$. The samples were diluted in $\mathrm{PBS} / 5 \% \mathrm{BSA}$ and incubated for $2 \mathrm{~h}$ at RT. After washing, POD-coupled anti-mouse IgM or IgG (Sigma-Aldrich, Taufkirchen, Germany) were added at 1:250 in PBS/5\% BSA for $1 \mathrm{~h}$ at RT, followed by substrate development with TMB reagent (BD Biosciences). $\mathrm{OD}$ at $450 \mathrm{~nm}$ was determined with an ELISA reader (Sunrise, Tecan, Männedorf, Switzerland). 


\section{Statistical analysis}

Data are given as mean values \pm standard deviation $(\mathrm{SD})$. Student's $t$ test was used to determine statistical significances, with ${ }^{*} \mathrm{p}<0.05,{ }^{* * *} \mathrm{p}<0.01$ and ${ }^{* * * *} \mathrm{p}<0.001$.

\section{Abbreviations}

ifen.: Ifenprodil; IO: Ionomycin; mem.: Memantine; NMDAR(s): N-methyl-Daspartate receptor(s)

\section{Competing interests}

The authors declare that they have no competing interests.

\section{Authors' contributions}

$\mathrm{UB}$ and $\mathrm{MH}$ designed the study and performed analysis. NS, TB, SK, JM, TL, $\mathrm{FL}$, and UB performed experiments and analysed data. BS and TS provided reagents and discussion. SK, TB, TS, MH, and UB wrote the manuscript. All authors read and approved the final manuscript.

\section{Authors' information}

Martin Heine and Ursula Bommhardt share senior authorship.

\section{Acknowledgements}

We thank G. Weitz for technical assistance and our colleagues for their support. We thank J. Hühn and R. Teich for providing IL-10-GFP reporter mice, S. Kliche and E. Serfling for Abs and discussion. N.S. was supported by a stipend from the Medical Faculty Magdeburg and N.S. and T.B. were supported by grant SFB854-TP9 from the Deutsche Forschungsgemeinschaft (DFG) to M.H. and U.B.

\section{Author details}

'Institute of Molecular and Clinical Immunology,

Otto-von-Guericke-University Magdeburg, Leipziger Str. 44, 39120 Magdeburg, Germany. ${ }^{2}$ RG Molecular Physiology, Leibniz Institute of Neurobiology, Brenneckestr. 6, 39118 Magdeburg, Germany. ${ }^{3}$ Department of Neuroimmunology, Institute for Multiple Sclerosis Research and The Hertie Foundation, Waldweg 33, 37073 Göttingen, Germany. ${ }^{4}$ Department of Immune Control, Helmholtz Centre for Infection Research, Inhoffenstr. 7 38124 Braunschweig, Germany.

Received: 30 April 2014 Accepted: 12 November 2014

Published online: 05 December 2014

\section{References}

1. LeBien TW, Tedder TF: B lymphocytes: how they develop and function. Blood 2008, 112(5):1570-1580.

2. Poltorak A, He X, Smirnova I, Liu MY, Van Huffel C, Du X, Birdwell D, Alejos E, Silva M, Galanos C, Freudenberg M, Ricciardi-Castagnoli P, Layton B, Beutler B: Defective LPS signaling in C3H/HeJ and C57BL/10ScCr mice: mutations in Tlr4 gene. Sci (New York, NY 1998, 282(5396):2085-2088.

3. Browne EP: Regulation of B-cell responses by Toll-like receptors. Immunology 2012, 136(4):370-379.

4. Beutler B, Poltorak A: Sepsis and evolution of the innate immune response. Crit Care Med 2001, 29(7 Suppl):S2-6. discussion S6-7.

5. lanaro A, Tersigni M, D'Acquisto F: New insight in LPS antagonist. Mini Rev Med Chem 2009, 9(3):306-317.

6. Rauch PJ, Chudnovskiy A, Robbins CS, Weber GF, Etzrodt M, Hilgendorf I, Tiglao E, Figueiredo JL, Iwamoto Y, Theurl I, Gorbatov R, Waring MT, Chicoine AT, Mouded M, Pittet MJ, Nahrendorf M, Weissleder R, Swirski FK: Innate response activator B cells protect against microbial sepsis. $S c i$ (New York, NY 2012, 335(6068):597-601.

7. Yanaba K, Bouaziz JD, Matsushita T, Magro CM, St Clair EW, Tedder TF: B-lymphocyte contributions to human autoimmune disease. Immunol Rev 2008, 223:284-299

8. Martinez-Hernandez E, Horvath J, Shiloh-Malawsky Y, Sangha N, MartinezLage M, Dalmau J: Analysis of complement and plasma cells in the brain of patients with anti-NMDAR encephalitis. Neurology 2011, 77(6):589-593.

9. Danysz W, Parsons CG: Alzheimer's disease, beta-amyloid, glutamate, NMDA receptors and memantine-searching for the connections. Br J Pharmacol 2012, 167(2):324-352.
10. Cunningham C: Microglia and neurodegeneration: the role of systemic inflammation. Glia 2013, 61(1):71-90.

11. Engelke M, Engels N, Dittmann K, Stork B, Wienands J: $\mathrm{Ca}(2+)$ signaling in antigen receptor-activated B lymphocytes. Immunol Rev 2007, 218:235-246.

12. Gwack Y, Feske S, Srikanth S, Hogan PG, Rao A: Signalling to transcription: store-operated $\mathrm{Ca} 2+$ entry and NFAT activation in lymphocytes. Cell Calcium 2007, 42(2):145-156.

13. Baba $Y$, Matsumoto M, Kurosaki T: Calcium signaling in B cells: regulation of cytosolic Ca increase and its sensor molecules, STIM1 and STIM2. Mol Immunol 2014, 62(2):339-343.

14. Churpilo S, Jankevics E, Tyrsin D, Akimzhanov A, Moroz D, Jha MK, SchulzeLuehrmann J, Santner-Nanan B, Feoktistova E, Konig T, Avots A, Schmitt E, Berberich-Siebelt F, Schimpl A, Serfling E: Autoregulation of NFATc1/A expression facilitates effector $T$ cells to escape from rapid apoptosis. Immunity 2002, 16(6):881-895.

15. Shaw PJ, Qu B, Hoth M, Feske S: Molecular regulation of CRAC channels and their role in lymphocyte function. Cell Mol Life Sci 2013, 70(15):2637-2656.

16. Okkenhaug K, Vanhaesebroeck B: PI3K in lymphocyte development, differentiation and activation. Nat Rev 2003, 3(4):317-330.

17. Engels N, Engelke M, Wienands J: Conformational plasticity and navigation of signaling proteins in antigen-activated B lymphocytes. Adv Immunol 2008, 97:251-281.

18. Bhattacharyya S, Deb J, Patra AK, Thuy Pham DA, Chen W, Vaeth M, Berberich-Siebelt F, Klein-Hessling S, Lamperti ED, Reifenberg K, Jellusova J, Schweizer A, Nitschke L, Leich E, Rosenwald A, Brunner C, Engelmann S, Bommhardt U, Avots A, Muller MR, Kondo E, Serfling E: NFATc1 affects mouse splenic $B$ cell function by controlling the calcineurin-NFAT signaling network. J Exp Med 2011, 208(4):823-839.

19. Pierau M, Na SY, Simma N, Lowinus T, Marx A, Schraven B, Bommhardt UH: Constitutive Akt1 signals attenuate B-cell receptor signaling and proliferation, but enhance B-cell migration and effector function. Eur J Immunol 2012, 42(12):3381-3393.

20. Castello A, Gaya M, Tucholski J, Oellerich T, Lu KH, Tafuri A, Pawson T, Wienands J, Engelke M, Batista FD: Nck-mediated recruitment of BCAP to the BCR regulates the PI(3)K-Akt pathway in B cells. Nat Immunol 2013, 14(9):966-975

21. Geppert TD, Whitehurst CE, Thompson P, Beutler B: Lipopolysaccharide signals activation of tumor necrosis factor biosynthesis through the ras/raf-1/MEK/MAPK pathway. Mol Med 1994, 1(1):93-103.

22. Vivarelli MS, McDonald D, Miller M, Cusson N, Kelliher M, Geha RS: RIP links TLR4 to Akt and is essential for cell survival in response to LPS stimulation. J Exp Med 2004, 200(3):399-404.

23. Over B, Ziegler S, Foermer S, Weber AN, Bode KA, Heeg K, Bekeredjian-Ding I: IRAK4 turns IL-10+ phospho-FOXO+ monocytes into pro-inflammatory cells by suppression of protein kinase B. Eur J Immuno/ 2013, 43(6):1630-1642.

24. Yanaba K, Bouaziz JD, Haas KM, Poe JC, Fujimoto M, Tedder TF: A regulatory $B$ cell subset with a unique $C D 1$ dhiCD5+ phenotype controls T cell-dependent inflammatory responses. Immunity 2008, 28(5):639-650.

25. Fillatreau S, Gray D, Anderton SM: Not always the bad guys: B cells as regulators of autoimmune pathology. Nat Rev 2008, 8(5):391-397.

26. Candando KM, Lykken JM, Tedder TF: B10 cell regulation of health and disease. Immunol Rev 2014, 259(1):259-272.

27. Madan R, Demircik F, Surianarayanan S, Allen IL, Divanovic S, Trompette A Yogev N, Gu Y, Khodoun M, Hildeman D, Boespflug N, Fogolin MB, Grobe L, Greweling M, Finkelman FD, Cardin R, Mohrs M, Muller W, Waisman A, Roers A, Karp CL: Nonredundant roles for B cell-derived IL-10 in immune counter-regulation. J Immunol 2009, 183(4):2312-2320.

28. Yanaba K, Bouaziz JD, Matsushita T, Tsubata T, Tedder TF: The development and function of regulatory B cells expressing IL-10 (B10 cells) requires antigen receptor diversity and TLR signals. J Immunol 2009, 182(12):7459-7472.

29. Blair PA, Chavez-Rueda KA, Evans JG, Shlomchik MJ, Eddaoudi A, Isenberg $D A$, Ehrenstein MR, Mauri C: Selective targeting of B cells with agonistic anti-CD40 is an efficacious strategy for the generation of induced regulatory T2-like B cells and for the suppression of lupus in MRL/lpr mice. J Immunol 2009, 182(6):3492-3502.

30. Poe JC, Smith SH, Haas KM, Yanaba K, Tsubata T, Matsushita T, Tedder TF: Amplified B lymphocyte CD40 signaling drives regulatory B10 cell expansion in mice. PLoS One 2011, 6(7):e22464.

31. DiLillo DJ, Matsushita T, Tedder TF: B10 cells and regulatory B cells balance immune responses during inflammation, autoimmunity, and cancer. Ann N Y Acad Sci 2010, 1183:38-57. 
32. Yoshizaki A, Miyagaki T, DiLillo DJ, Matsushita T, Horikawa M, Kountikov El, Spolski R, Poe JC, Leonard WJ, Tedder TF: Regulatory B cells control T-cell autoimmunity through IL-21-dependent cognate interactions. Nature 2012, 491(7423):264-268.

33. Fillatreau S, Sweenie CH, McGeachy MJ, Gray D, Anderton SM: B cells regulate autoimmunity by provision of IL-10. Nat Immunol 2002, 3(10):944-950.

34. Matsushita T, Yanaba K, Bouaziz JD, Fujimoto M, Tedder TF: Regulatory B cells inhibit EAE initiation in mice while other $B$ cells promote disease progression. J Clin Invest 2008, 118(10):3420-3430.

35. Mauri C, Gray D, Mushtaq N, Londei M: Prevention of arthritis by interleukin 10-producing B cells. J Exp Med 2003, 197(4):489-501.

36. Mizoguchi A, Mizoguchi E, Takedatsu H, Blumberg RS, Bhan AK: Chronic intestinal inflammatory condition generates IL-10-producing regulatory B cell subset characterized by CD1d upregulation. Immunity 2002, 16(2):219-230

37. Lancaster E, Martinez-Hernandez E, Dalmau J: Encephalitis and antibodies to synaptic and neuronal cell surface proteins. Neurology 2011, 77(2):179-189.

38. Kleopa KA: Autoimmune channelopathies of the nervous system. Curr Neuropharmacol 2011, 9(3):458-467.

39. Rogers SW, Andrews PI, Gahring LC, Whisenand T, Cauley K, Crain B, Hughes TE, Heinemann SF, McNamara JO: Autoantibodies to glutamate receptor GluR3 in Rasmussen's encephalitis. Sci (New York, NY 1994, 265(5172):648-651.

40. Lennon VA, Kryzer TJ, Griesmann GE, O'Suilleabhain PE, Windebank AJ, Woppmann A, Miljanich GP, Lambert EH: Calcium-channel antibodies in the Lambert-Eaton syndrome and other paraneoplastic syndromes. N Engl J Med 1995, 332(22):1467-1474.

41. Sansing LH, Tuzun E, Ko MW, Baccon J, Lynch DR, Dalmau J: A patient with encephalitis associated with NMDA receptor antibodies. Nat Clin Pract Neurol 2007, 3(5):291-296.

42. Ramanathan S, Mohammad SS, Brilot F, Dale RC: Autoimmune encephalitis: recent updates and emerging challenges. J Clin Neurosci 2014, 21(5):722-730

43. Rawlings DJ, Schwartz MA, Jackson SW, Meyer-Bahlburg A: Integration of B cell responses through Toll-like receptors and antigen receptors. Nat Rev 2012, 12(4):282-294.

44. Peri F, Piazza M: Therapeutic targeting of innate immunity with Toll-like receptor 4 (TLR4) antagonists. Biotechnol Adv 2012, 30(1):251-260.

45. Traynelis SF, Wollmuth LP, McBain CJ, Menniti FS, Vance KM, Ogden KK, Hansen KB, Yuan H, Myers SJ, Dingledine R: Glutamate receptor ion channels: structure, regulation, and function. Pharmacol Rev 2010, 62(3):405-496

46. Parsons CG, Danysz W, Dekundy A, Pulte I: Memantine and cholinesterase inhibitors: complementary mechanisms in the treatment of Alzheimer's disease. Neurotox Res 2013, 24(3):358-369.

47. Murrough JW, losifescu DV, Chang LC, Al Jurdi RK, Green CE, Perez AM, lqbal S, Pillemer S, Foulkes A, Shah A, Charney DS, Mathew SJ: Antidepressant efficacy of ketamine in treatment-resistant major depression: a two-site randomized controlled trial. Am J Psychiatry 2013, 170(10):1134-1142.

48. Lipton SA: Pathologically activated therapeutics for neuroprotection. Nat Rev Neurosci 2007, 8(10):803-808.

49. Santangelo RM, Acker TM, Zimmerman SS, Katzman BM, Strong KL, Traynelis SF, Liotta DC: Novel NMDA receptor modulators: an update. Expert Opin Ther Pat 2012, 22(11):1337-1352.

50. Dang VD, Hilgenberg $E$, Ries $S$, Shen $P$, Fillatreau S: From the regulatory functions of B cells to the identification of cytokine-producing plasma cell subsets. Curr Opin Immunol 2014, 28C:77-83.

51. Kacimi R, Giffard RG, Yenari MA: Endotoxin-activated microglia injure brain derived endothelial cells via NF-kappaB, JAK-STAT and JNK stress kinase pathways. J Inflamm (Lond) 2011, 8:7

52. Cull-Candy S, Brickley S, Farrant M: NMDA receptor subunits: diversity, development and disease. Curr Opin Neurobiol 2001, 11(3):327-335.

53. Kahlfuss S, Simma N, Mankiewicz J, Bose T, Lowinus T, Klein-Hessling S, Sprengel R, Schraven B, Heine M, Bommhardt U: Immunosuppression by N-Methyl-D-Aspartate Receptor Antagonists Is Mediated through Inhibition of Kv1.3 and KCa3.1 Channels in T Cells. Mol Cell Biol 2014, 34(5):820-831.

54. Lam J, Wulff H: The Lymphocyte Potassium Channels Kv1.3 and KCa3.1 as Targets for Immunosuppression. Drug Dev Res 2011, 72(7):573-584.
55. Cahalan MD, Chandy KG: Ion channels in the immune system as targets for immunosuppression. Curr Opin Biotechnol 1997, 8(6):749-756.

56. Amigorena S, Choquet D, Teillaud JL, Korn H, Fridman WH: Ion channel blockers inhibit B cell activation at a precise stage of the $\mathrm{G} 1$ phase of the cell cycle. Possible involvement of K+ channels. J Immunol 1990, 144(6):2038-2045.

57. Partiseti M, Choquet D, Diu A, Korn H: Differential regulation of voltageand calcium-activated potassium channels in human B lymphocytes. J Immunol 1992, 148(11):3361-3368.

58. Partiseti $\mathrm{M}$, Korn $\mathrm{H}$, Choquet D: Pattern of potassium channel expression in proliferating $B$ lymphocytes depends upon the mode of activation. J Immunol 1993, 151(5):2462-2470.

59. Wulff H, Knaus HG, Pennington M, Chandy KG: K+ channel expression during $B$ cell differentiation: implications for immunomodulation and autoimmunity. J Immunol 2004, 173(2):776-786.

60. Lewis RS, Cahalan MD: Potassium and calcium channels in lymphocytes. Annu Rev Immunol 1995, 13:623-653.

61. Ackermann JA, Radtke D, Maurberger A, Winkler TH, Nitschke L: Grb2 regulates $\mathrm{B}$-cell maturation, $\mathrm{B}$-cell memory responses and inhibits $\mathrm{B}$-cell Ca2+ signalling. EMBO J 2011, 30(8):1621-1633.

62. Hock M, Vaeth M, Rudolf R, Patra AK, Pham DA, Muhammad K, Pusch T, Bopp T, Schmitt E, Rost R, Berberich-Siebelt F, Tyrsin D, Chuvpilo S, Avots A, Serfling $E$, Klein-Hessling S: NFATc1 induction in peripheral T and B lymphocytes. J Immunol 2013, 190(5):2345-2353.

63. Matsumoto M, Fujii Y, Baba A, Hikida M, Kurosaki T, Baba Y: The calcium sensors STIM1 and STIM2 control B cell regulatory function through interleukin-10 production. Immunity 2011, 34(5):703-714

64. Tian J, Zekzer D, Hanssen L, Lu Y, Olcott A, Kaufman DL: Lipopolysaccharide-activated B cells down-regulate Th1 immunity and prevent autoimmune diabetes in nonobese diabetic mice. J Immunol 2001, 167(2):1081-1089.

65. Kamanaka M, Kim ST, Wan YY, Sutterwala FS, Lara-Tejero M, Galan JE, Harhaj E, Flavell RA: Expression of interleukin-10 in intestinal lymphocytes detected by an interleukin-10 reporter knockin tiger mouse. Immunity 2006, 25(6):941-952.

66. Cahalan MD, Chandy KG: The functional network of ion channels in T lymphocytes. Immunol Rev 2009, 231(1):59-87.

67. Agrawal A, Dillon S, Denning TL, Pulendran B: ERK1-/- mice exhibit Th1 cell polarization and increased susceptibility to experimental autoimmune encephalomyelitis. J Immuno/ 2006, 176(10):5788-5796.

68. Qian C, Jiang X, An H, Yu Y, Guo Z, Liu S, Xu H, Cao X: TLR agonists promote ERK-mediated preferential IL-10 production of regulatory dendritic cells (diffDCs), leading to NK-cell activation. Blood 2006, 108(7):2307-2315

69. Jin G, Hamaguchi Y, Matsushita T, Hasegawa M, Le Huu D, Ishiura N, Naka K, Hirao A, Takehara K, Fujimoto M: B-cell linker protein expression contributes to controlling allergic and autoimmune diseases by mediating IL-10 production in regulatory B cells. J Allergy Clin Immunol 2013, 131(6):1674-1682.

70. Liu BS, Cao Y, Huizinga TW, Hafler DA, Toes RE: TLR-mediated STAT3 and ERK activation controls IL-10 secretion by human B cells. Eur J Immunol 2014, 44(7):2121-2129.

71. Saraiva M, O'Garra A: The regulation of IL-10 production by immune cells. Nat Rev 2010, 10(3):170-181.

72. Ziegler S, Gartner K, Scheuermann U, Zoeller T, Hantzschmann J, Over B, Foermer S, Heeg K, Bekeredjian-Ding I: $\mathrm{Ca}(2+)$-related signaling events influence TLR9-induced IL-10 secretion in human B cells. Eur J Immunol 2014, 44(5):1285-1298.

73. Iritani BM, Forbush KA, Farrar MA, Perlmutter RM: Control of B cell development by Ras-mediated activation of Raf. EMBO J 1997 16(23):7019-7031.

74. Jacob A, Cooney D, Pradhan M, Coggeshall KM: Convergence of signaling pathways on the activation of ERK in B cells. J Biol Chem 2002, 277(26):23420-23426.

75. Teixeira-Coelho M, Guedes J, Ferreirinha P, Howes A, Pedrosa J, Rodrigues F, Lai WS, Blackshear PJ, O'Garra A, Castro AG, Saraiva M: Differential posttranscriptional regulation of IL-10 by TLR2 and TLR4-activated macrophages. Eur J Immunol 2014, 44(3):856-866.

76. Maseda D, Smith SH, DiLillo DJ, Bryant JM, Candando KM, Weaver CT, Tedder TF: Regulatory B10 cells differentiate into antibody-secreting cells after transient IL-10 production in vivo. J Immunol 2012, 188(3):1036-1048. 
77. Quintana $A$, Pasche $M$, Junker $C$, Al-Ansary D, Rieger $H$, Kummerow $C$,

Nunez L, Villalobos C, Meraner P, Becherer U, Rettig J, Niemeyer BA, Hoth M: Calcium microdomains at the immunological synapse: how ORAI channels, mitochondria and calcium pumps generate local calcium signals for efficient T-cell activation. EMBO J 2011, 30(19):3895-3912.

78. Gocke AR, Lebson LA, Grishkan IV, Hu L, Nguyen HM, Whartenby KA, Chandy KG, Calabresi PA: Kv1.3 deletion biases T cells toward an immunoregulatory phenotype and renders mice resistant to autoimmune encephalomyelitis. J Immunol 2012, 188(12):5877-5886.

79. Koshy S, Huq R, Tanner MR, Atik MA, Porter PC, Khan FS, Pennington MW, Hanania NA, Corry DB, Beeton C: Blocking KV1.3 channels inhibits Th2 lymphocyte function and treats a rat model of asthma. J Biol Chem 2014, 289(18):12623-12632.

80. Chen YJ, Lam J, Gregory CR, Schrepfer S, Wulff H: The Ca(2)(+)-activated K $(+)$ channel KCa3.1 as a potential new target for the prevention of allograft vasculopathy. PLoS One 2013, 8(11):e81006.

81. Grgic I, Kiss E, Kaistha BP, Busch C, Kloss M, Sautter J, Muller A, Kaistha A, Schmidt C, Raman G, Wulf H, Strutz F, Grone HJ, Kohler R, Hoyer J: Renal fibrosis is attenuated by targeted disruption of KCa3.1 potassium channels. Proc Natl Acad Sci U S A 2009, 106(34):14518-14523.

82. Pierau M, Engelmann S, Reinhold D, Lapp T, Schraven B, Bommhardt UH: Protein kinase B/Akt signals impair Th17 differentiation and support natural regulatory $T$ cell function and induced regulatory $T$ cell formation. J Immunol 2009, 183(10):6124-6134.

83. Vallejo-Gracia A, Bielanska J, Hernandez-Losa J, Castellvi J, Ruiz-Marcellan MC, Ramon Y, Cajal S, Condom E, Manils J, Soler C, Comes N, Ferreres JC, Felipe A: Emerging role for the voltage-dependent $\mathrm{K}+$ channel Kv1.5 in B-lymphocyte physiology: expression associated with human lymphoma malignancy. J Leukoc Biol 2013, 94(4):779-789.

doi:10.1186/s12964-014-0075-5

Cite this article as: Simma et al.: NMDA-receptor antagonists block B-cell function but foster IL-10 production in BCR/CD40-activated B cells. Cell Communication and Signaling 2014 12:75.

\section{Submit your next manuscript to BioMed Central and take full advantage of:}

- Convenient online submission

- Thorough peer review

- No space constraints or color figure charges

- Immediate publication on acceptance

- Inclusion in PubMed, CAS, Scopus and Google Scholar

- Research which is freely available for redistribution 